\title{
鋳造プリカーサ法によるポーラスアルミニウムの作製
}

\author{
鈴木良祐＼cjkstart西本拓真* 半谷禎彦＼cjkstart荘司郁夫＼cjkstart松原雅紹
}

群馬大学大学院理工学府

J. Japan Inst. Met. Mater. Vol. 82, No. 9 (2018), pp. 349-357

(C) 2018 The Japan Institute of Metals and Materials

\section{Fabrication of Aluminum Foam by Casting Precursor Method}

\author{
Ryosuke Suzuki, Takuma Nishimoto*, Yoshihiko Hangai, Ikuo Shoji and Masaaki Matsubara \\ Graduate School of Science and Technology, Gunma University, Kiryu 376-8515
}

This study proposes a casting precursor method for low-cost manufacture of large aluminum foams with complex shapes. We experimentally investigated whether a precursor with low porosity can be used to fabricate an aluminum foam with high porosity. Pure aluminum powder and alumina powder as a thickening agent were added to a molten ADC12 aluminum alloy, and the melt was mixed. Then, titanium hydride powder as a foaming agent was added to the melt, and it was mixed again. The melt was poured into a copper mold and a columnar foamable precursor was obtained. An aluminum foam with maximum porosity of $80 \%$ was obtained by heating the precursor ( 1 mass \% pure aluminum powder, 1 mass \% alumina powder, 1.5 mass $\%$ titanium hydride powder and 96.5 mass \% ADC12 aluminum alloy) at $948 \mathrm{~K}$ for $7 \mathrm{~min}$. The compressive behavior of the produced aluminum foam was close to that of an $\mathrm{ADC1} 2$ aluminum foam made in previous research, indicating that the new approach has promise. However, the precursor had about $40 \%$ porosity because the titanium hydride decomposed during casting. Thus, we attempted to prevent decomposition of the foaming agent during the casting process. The porosity was increased by increasing the amount of pure aluminum powder added. In contrast, increasing the amount of alumina powder added had almost no effect on porosity because the alumina particles did not disperse fully in the melt due to their low wettability with alumina. The titanium hydride powder was heat treated to prevent its decomposition during the casting process. The heat-treated powder decreased the porosity of the precursor, but the porosity of the aluminum foam also decreased. A low-cost foaming agent with a decomposition temperature higher than that of titanium hydride is needed for low-cost manufacture of aluminum foam by the casting precursor method. [doi:10.2320/jinstmet.J2018016]

(Received March 13, 2018; Accepted May 21, 2018; Published June 29, 2018)

Keywords: aluminum foam, porous metal, casting, precursor, aluminum alloy

\section{1. 緒言}

環境負荷低減や燃費向上の観点から輸送機器の軽量化が重 要となっており, 軽量構造材料としてアルミニウム合金が広 く用いられている. 特に, 鉄道, 船舶, 航空機および宇宙機 といった大型輸送機に関しては, アルミニウムハニカムコア サンドイッチ(Aluminum Honeycomb Core Sandwich, AHCS) 材料 ${ }^{1)}$ が広く利用されている.コア材となるアルミニウムハ ニカムが薄肉構造体であり, コア材とスキン材の接合部の有 効接合面積が小さくなるため, コアとスキン材の接合が難し い.アルミニウムハニカムコアと板材を所定の形状に成形し てから接合させる必要があるので, 複雑形状の AHCS を作製 することは特に難しい.

作製の難しいAHCS の代替材料となる軽量材料として, ポーラスアルミニウムをコア材料としたポーラスアルミニウ ムコアサンドイッチ (Aluminum Foam Core Sandwich, AFCS) 材料 ${ }^{2-5}$ の利用が提案されている. ポーラスアルミニウムは多 数の気孔を内包したアルミニウム基複合材料である. 高気孔 率のポーラスアルミニウムは密度が $0.2 \mathrm{~g} / \mathrm{cm}^{3}$ 以下にもなる 超軽量材料である. ポーラスアルミニウムの作製方法の一つ

\footnotetext{
* 群馬大学大学院生 (Graduate Student, Gunma University)
}

にプリカーサ法がある．プリカーサ法では高温でガスを放出 する発泡剂粒子と発泡過程で気孔を安定化させる増粘剂粒子 を均一に分散させた前駆体であるプリカーサを作製し，その プリカーサを高温に加熱して金属相の軟化・溶融および発泡 剤の分解に伴うガス放出を利用してポーラスアルミニウムを 得る ${ }^{2,6)}$. ポーラスアルミニウム作製過程において, 緻密なプ リカーサを得ることができるため, プリカーサにスキン材を 接合圧延などにより接合した後に加熱・発泡させることがで きるので, AHCSよりも簡単に AFCS を作製することが可能 である。

一般的なプリカーサ法である粉末法ではアルミニウム合金 粉末を素材として用いるため, 素材コストが高価である. 安 価な板材を素材として用いるプリカーサ法として圧延接合 (Accumulate Roll Bonding, ARB) 法 ${ }^{7,8)}$ や摩擦攪拌 (Friction Stir Processing, FSP) 法 ${ }^{9,10)}$ が提案されている.これらの方法では 複数枚の板材の間に発泡剂粉末および増粘剤粉末を挟んで圧 延接合または摩擦攪拌を繰り返し施すことで, 発泡剂粒子お よび増粘剂粒子が均一に分散したプリカーサを得る。しかし ながら, ARB 法では板材の接合界面に粉末を添加しての接合 が困難であり，FSP 法ではツールサイズが小さいため 1 パス での接合範囲が狭く数パスの摩擦攪拌を要するため生産性に 劣る. 切削屑のような廃材を素材として圧縮ねじり ${ }^{11,12)}$ のよ うな強ひずみ加工を利用してプリカーサを作製する方法も提 
案されているが，得られるプリカーサのサイズや生産性に問 題がある.

大型のポーラスアルミニウムを比較的安価に作製すること が可能な方法として鋳造を利用する方法がある ${ }^{6,13,14)}$. 鋳造を 利用する方法にはアルミニウム溶湯に発泡剂粉末を投入して 直接発泡させ, 凝固することによってポーラスアルミニウム を得る溶湯発泡法 ${ }^{6,14)}$ や，溶湯内に注入管を介してガスを吹き 込み, 気孔を導入した後, 凝固させてポーラスアルミニウム を製造する直接ガス吹込法 ${ }^{6,13)}$ がある。しかしながら，鋳造を 利用する方法では複雑形状のポーラスアルミニウムを作製す ることが困難である.

AFCS を広い工業分野で利用するためには，複雑形状かつ 大型のポーラスアルミニウムを安価に作製する方法が必要で ある。しかしながら，プリカーサ法は複雑形状部材の作製は 容易であるが素材が高価で生産性も低い，鋳造を利用する方 法では比較的安価にポーラスアルミニウムを得られるが複雑 形状部材の作製が困難である.

そこで，プリカーサ法と鋳造を利用する方法の利点を併せ 持つ鋳造プリカーサ法を提案する. 鋳造プリカーサ法では, アルミニウム溶湯に増粘剤および発泡剤を添加後攪拌して冷 却することで緻密なプリカーサを作製する．鋳造プリカーサ 法は，ポーラスアルミニウムの作製過程において緻密なプリ カーサを得ることができるため複雑形状部材の作製が容易で あり，プリカーサの作製に鋳造を用いるので素材は安価なア ルミニウム合金のバルク材料を用いることが可能であり生産 性もよい，本研究では，鋳造プリカーサ法を用いて緻密なプ リカーサおよび高気孔率ポーラスアルミニウムを作製できる か実験的に調べる．鋳造によるプリカーサ作製過程において 発泡剂が分解しにくい低融点 $\mathrm{Al}-\mathrm{Si}$ アルミニウム合金 $(\mathrm{ADC12})$ をマトリックスのモデル材料として，一般的に用いられてい る発泡剂である水素化チタン $\left(\mathrm{TiH}_{2}\right)$ 粉末を利用した。高気孔 率ポーラスアルミニウムを得るためにはマトリックスの粘度 が重要となるので，鋳造プリカーサ法により作製されるポー ラスアルミニウムの気孔率におよぼす増粘剤添加の影響につ いても調べた。プリカーサ作製過程における $\mathrm{TiH}_{2}$ の分解を抑 制するための方法として， $\mathrm{TiH}_{2}$ に熱処理を行う方法 ${ }^{15-17)}$ があ る. 本研究では, $\mathrm{TiH}_{2}$ の熱処理が鋳造プリカーサ法により作 製されるポーラスアルミニウムの気孔率におよぼす影響につ いても調べた.

\section{2. 実 験 方 法}

本研究ではプリカーサ作製中に発泡剂が分解しにくい低融 点の $\mathrm{ADC1}$ アアルミニウム合金をポーラスアルミニウムのマト リックスとして選択した。実験装置の模式図を Fig. 1 に示す. 加熱には自作の坩堝炉を用いた，ADC12アルミニウム合金を 溶解する坩堝として，日本ルツボ株式会社製 2 号の黒鉛坩堝 (口径 $\phi 85 \mathrm{~mm}$ ，底径 $\phi 60 \mathrm{~mm}$ および高さ $106 \mathrm{~mm}$ )を用いた。 $\mathrm{ADC} 12$ アルミニウム合金溶湯に増粘剤および発泡剂を分散さ せるため, 攪拌装置として東京理化器械株式会社製攪拌機 MAZELA ZZ-2121を用いた，攪拌にはスリーワンモータ社製 汎用攪拌翼 $\phi 38 \mathrm{~mm}$ ファンを先端に, $\phi 50 \mathrm{~mm}$ ボス付きプロ

ペラ $\mathrm{R}$ を先端から $20 \mathrm{~mm}$ の位置に取り付けた $\phi 8 \mathrm{~mm}$ 長さ $500 \mathrm{~mm}$ のステンレス攪拌軸を用い攪拌した。攪拌前に攪拌 軸および覺拌翼には BN スプレーを塗布した。

プリカーサ作製方法を Fig. 2 に示す. ADC12アルミニウム 合金約 $80 \mathrm{~g}$ を坩堝に入れ，坩堝ごと坩堝炉に挿入し溶湯温度 が 873 K になるまで大気䨌囲気で加熱し， $\mathrm{ADC} 12$ アルミニウ ム合金を溶融した。 $\mathrm{ADC} 12$ アルミニウム合金溶湯に増粘剤と して，作製されるプリカーサの質量に対して純アルミニウム 粉末(粒子径 $d_{\mathrm{Al}} \approx 3 \mu \mathrm{m}$ ) 1.0 mass\%および $\mathrm{Al}_{2} \mathrm{O}_{3}$ 粉末(粒子径 $\left.d_{\mathrm{A} 1203} \leqq 1 \mu \mathrm{m}\right) 1.0$ mass\%を添加して $500 \mathrm{rpm}$ で $20 \mathrm{~min}$ 攪拌し た。溶融したマトリックス中に微細な粒子があると溶融マト リックスの粘度が高くなり, 気孔が安定することが知られて いる ${ }^{18-21)}$. 純アルミニウム粉末は粉体表面に存在する酸化物 の破壊と分散により溶湯の粘性を増加させる目的で鋳造法に よるポーラスアルミニウム作製において増粘剤として利用さ

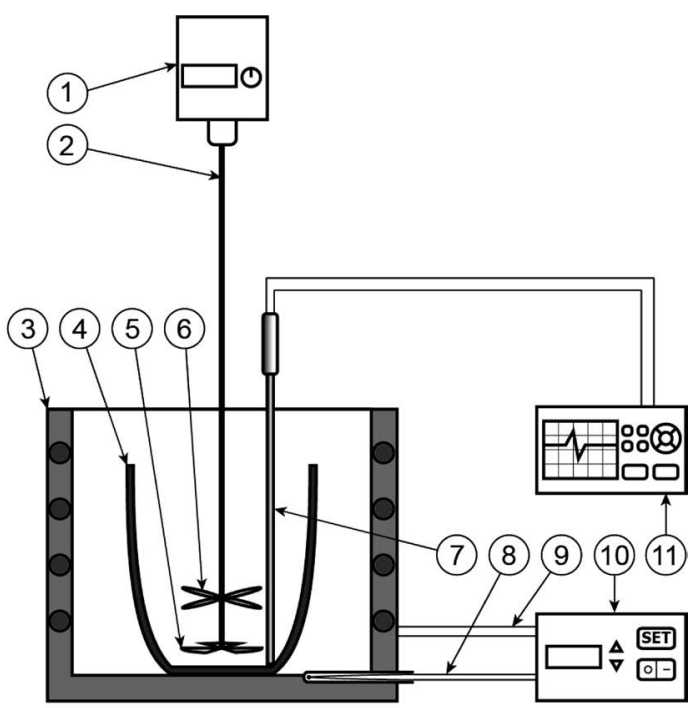

(1)Agitating device, (2) Stirring shaft, (3) Crucible furnace, (4) Graphite crucible, (5) 3-bladed fan $(\varphi 38)$,

(6) 4-bladed propeller $(\varphi 50)$, (7) Sheathed thermocouple

(8) Thermocouple, (9) Conducting wire,

(10) Temperature controller, (11) Data logger

Fig. 1 Experimental setup.

(a) Crucible furnace (b) Thickening agent ${ }^{\text {(c) }}$ Foaming agent

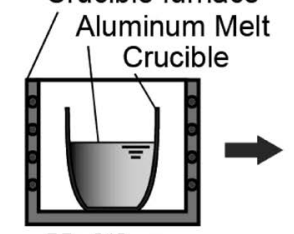

Melting

(d)

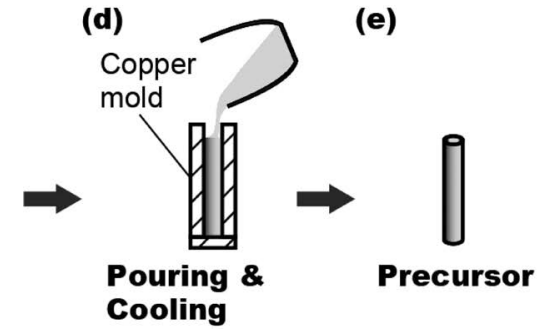

Fig. 2 Manufacturing process of the foamable precursor. 
れており 22-24), $\mathrm{Al}_{2} \mathrm{O}_{3}$ 粉末は鋳造法のみではなくプリカーサ法 に関するポーラスアルミニウムの研究においてもよく増粘剤 として利用されている ${ }^{11,20,25)}$.

増粘した溶湯に発泡剤として $\mathrm{TiH}_{2}$ 粉末 (粒子径 $45 \mu \mathrm{m}$ 以下) を 1.5 mass\%添加し $1200 \mathrm{rpm}$ で $1 \mathrm{~min}$ 攪汼した。増粘剤お よび発泡剂の粒子を分散させた溶湯を内径 $\phi 15 \mathrm{~mm}$ 高さ 200 $\mathrm{mm}$ の銅製金型に注湯した。これを空冷したのち，金型より 取り出すことでプリカーサを得た。このプリカーサに関する 試験片を以後 Normal と呼ぶこととする，走査型電子顕微鏡 (SEM) を用いて Normal プリカーサの断面の反射電子像 (BEI) を観察した.

発泡体の気孔率におよぼす増粘効果の影響を調べるため, $\mathrm{Al}_{2} \mathrm{O}_{3}$ 粉末 0 mass $\% \mathrm{TiH}_{2}$ 粉末 1.5 mass \%および純アルミニウ 么粉末添加量が $n_{\mathrm{Al}}=0 ， 1 ， 1.5 ， 2$ および 3 mass $\%$ と異な るプリカーサを作製した。 このプリカーサに関する試験片を 以後 PAlC と呼ぶこととする. 同様に純アルミニウム粉末 1 mass $\% \mathrm{TiH}_{2}$ 粉末 1.5 mass\%およ゙ $\mathrm{Al}_{2} \mathrm{O}_{3}$ 粉末添加量が $n_{\mathrm{Al} 2 \mathrm{O} 3}=0 ， 1 ， 2$ および 4 mass $\%$ と異なるプリカーサを作 製した。このプリカーサに関する試験片を以後 $\mathrm{Al}_{2} \mathrm{O}_{3} \mathrm{C}$ と呼ぶ こととする.

プリカーサ作製過程における $\mathrm{TiH}_{2}$ の分解を抑制するために $\mathrm{TiH}_{2}$ 粉末を熱処理温度 $T=773 \mathrm{~K}^{15}$ または $823 \mathrm{~K}^{15)}$ で $2 \mathrm{~h}$ の間, 大気雲囲気中で保持する熱処理を行った。気孔率におよぼす $\mathrm{TiH}_{2}$ 粉末への熱処理の影響を検討するために, 純アルミニウ ム粉末 1 mass \%, $\mathrm{Al}_{2} \mathrm{O}_{3}$ 粉末 1 mass\%および熱処理した $\mathrm{TiH}_{2}$ 粉末 1.5 mass \%を溶湯に添加したプリカーサを作製した。こ のプリカーサに関する試験片を以後 $\mathrm{TiH}_{2} \mathrm{C}$ と呼ぶこととする. PAlC, $\mathrm{Al}_{2} \mathrm{O}_{3} \mathrm{C}$ および $\mathrm{TiH}_{2} \mathrm{C}$ プリカーサの作製には Normal プ リカーサを作製したものと同じ実験装置を用い，作製時の炉 温, 雲囲気および覺拌時間も Normal プリカーサ作製時と同 様とした. Normal, PAlC, $\mathrm{Al}_{2} \mathrm{O}_{3} \mathrm{C}$ および $\mathrm{TiH}_{2} \mathrm{C}$ プリカーサ の作製条件について Table 1 にまとめる。 $\mathrm{TiH}_{2}$ の熱処理をし なかった試験片に関しては, $\mathrm{TiH}_{2}$ の熱処理温度 Tの闌には 300 $\mathrm{K}$ (室温)と表記する.

Normal, PAlC, $\mathrm{Al}_{2} \mathrm{O}_{3} \mathrm{C}$ および $\mathrm{TiH}_{2} \mathrm{C}$ プリカーサを $\phi 15$ $\mathrm{mm} \times 10 \mathrm{~mm}$ の円柱状の試験片に切り出した。金型の底部か らプリカーサの中心位置までの距離を $x$ として定義した (Fig. 3). 切り出した試験片の密度 $\rho_{\mathrm{f}}$ をアルキメデス法で測定し次 式を用いて気孔率 $p(\%)$ を算出した.

$$
p=\left(1-\frac{\rho_{f}}{\rho_{i}}\right) \times 100
$$

ここで， $\rho_{\mathrm{i}}$ は試験片の理論密度である。試験片をセラミック

Table 1 Kinds of the specimens fabricated in the study.

\begin{tabular}{ccccc}
\hline & $\begin{array}{c}n_{\mathrm{Al}} \\
\text { mass } \%\end{array}$ & $\begin{array}{c}n_{\mathrm{Al} 2 \mathrm{O} 3} \\
\text { mass } \%\end{array}$ & $\begin{array}{c}n_{\mathrm{TiH} 2} \\
\text { mass } \%\end{array}$ & $\begin{array}{c}T \\
\mathrm{~K}\end{array}$ \\
\hline Normal & 1 & 1 & 1.5 & 300 \\
PAIC & $0,1,1.5,2$ & 0 & 1.5 & 300 \\
$\mathrm{Al}_{2} \mathrm{O}_{3} \mathrm{C}$ & 1 & $0,1,2,4$ & 1.5 & 300 \\
$\mathrm{TiH}_{2} \mathrm{C}$ & 1 & 1 & 1.5 & 773,823 \\
\hline
\end{tabular}

スセッターの上に載せて $948 \mathrm{~K} に$ 加熱した電気炉内に挿入し, 大気雲囲気で 7 min 保持したのち, 取り出して空冷する発泡 試験を行った。 その後, アルキメデス法で密度測定を行い, 式 (1) を用いて試験片の気孔率を求めた。試験片を半分に切 断しセル形態を観察した. 試験片の断面を写真撮影し画像解 析ソフト image J (ver. 1.451) を用いて気孔の面積を求め, 最大 気孔径 $d_{\max }$ および平均気孔径 $d_{\mathrm{m}}$ を相当円直径として算出し た。

$$
\begin{aligned}
& d_{\max }=\sqrt{\frac{4 A_{\max }}{\pi}} \\
& d_{\mathrm{m}}=\frac{1}{n} \sum_{i=1}^{n} \sqrt{\frac{4 A_{i}}{\pi}}
\end{aligned}
$$

ここで, $A_{\max }$ は気孔面積の最大值， $A_{i}$ は気孔一つの面積およ び $n$ は気孔の総数である. 気孔径のばらつきを確認するため に標準偏差 $\sigma_{\mathrm{p}}$ も求めた.

鋳造プリカーサ法で作製されるポーラスアルミニウムの機 械的特性を調べるため, Normal プリカーサを内径 $\phi 16 \mathrm{~mm}$ のステンレス製薄肉円管に挿入し， $948 \mathrm{~K}$ に加熱した電気炉 内で $7 \mathrm{~min}$ 発泡させ, $\phi 15 \mathrm{~mm} \times 15 \mathrm{~mm}$ の試験片に切り出し た. 油圧万能試験機を用いてクロスヘッド速度 $1 \mathrm{~mm} / \mathrm{min}$ で Normal ポーラスアルミニウムの圧縮試験を行った．比較のた めに神鋼鋼線工業製のポーラスアルミニウム ALPORAS ${ }^{14)}$ か ら一辺 $17 \mathrm{~mm}$ の立方体試験片を切り出して同様の圧縮試験を 行った.

\section{3. 実験結果および考察}

\section{1 プリカーサ}

Normal プリカーサの気孔率を試験片位置の関数として Fig. 4 に示す。底部から $20 \mathrm{~mm}$ までの気孔率は $10 \%$ 未満であっ た.一方, $20 \mathrm{~mm}$ 以降は気孔率が約 $40 \%$ と比較的高くなった. PAlC, $\mathrm{Al}_{2} \mathrm{O}_{3} \mathrm{C}$ および $\mathrm{TiH}_{2} \mathrm{C}$ プリカーサの気孔率も Normal プ リカーサの気孔率と同様に底部近傍で低く，それ以外で高く なった。

$x=5 \mathrm{~mm}$ および $x=55 \mathrm{~mm}$ の Normal プリカーサの断面の SEM 観察結果を Fig. 5 に示す．反射電子像は原子番号が大き

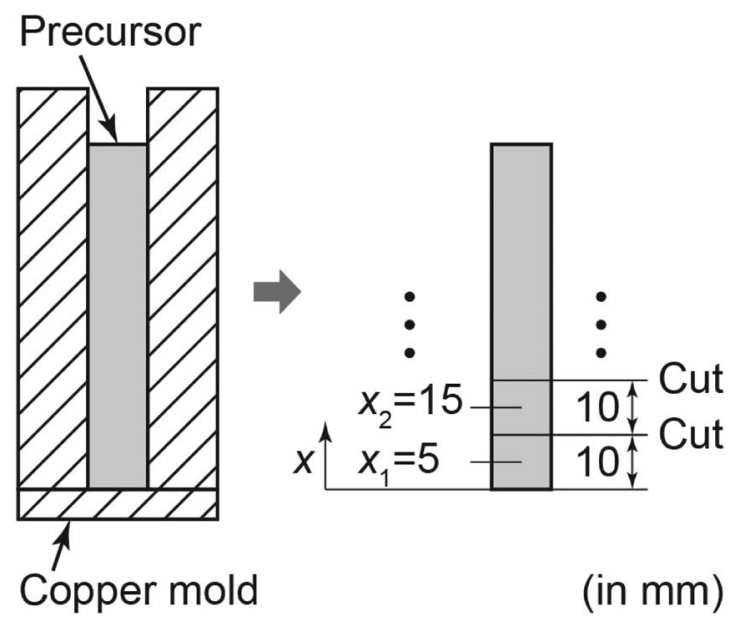

Fig. 3 Coordinate of the precursor. 


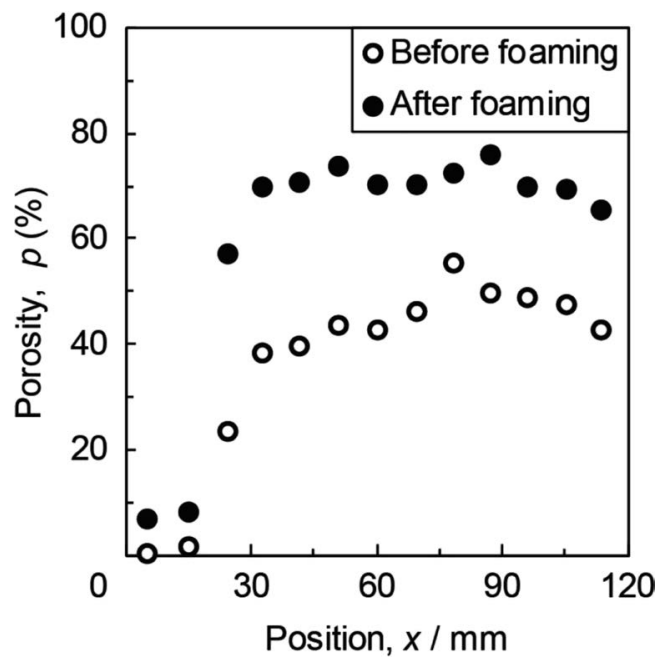

Fig. 4 Porosity plotted as a function of position.
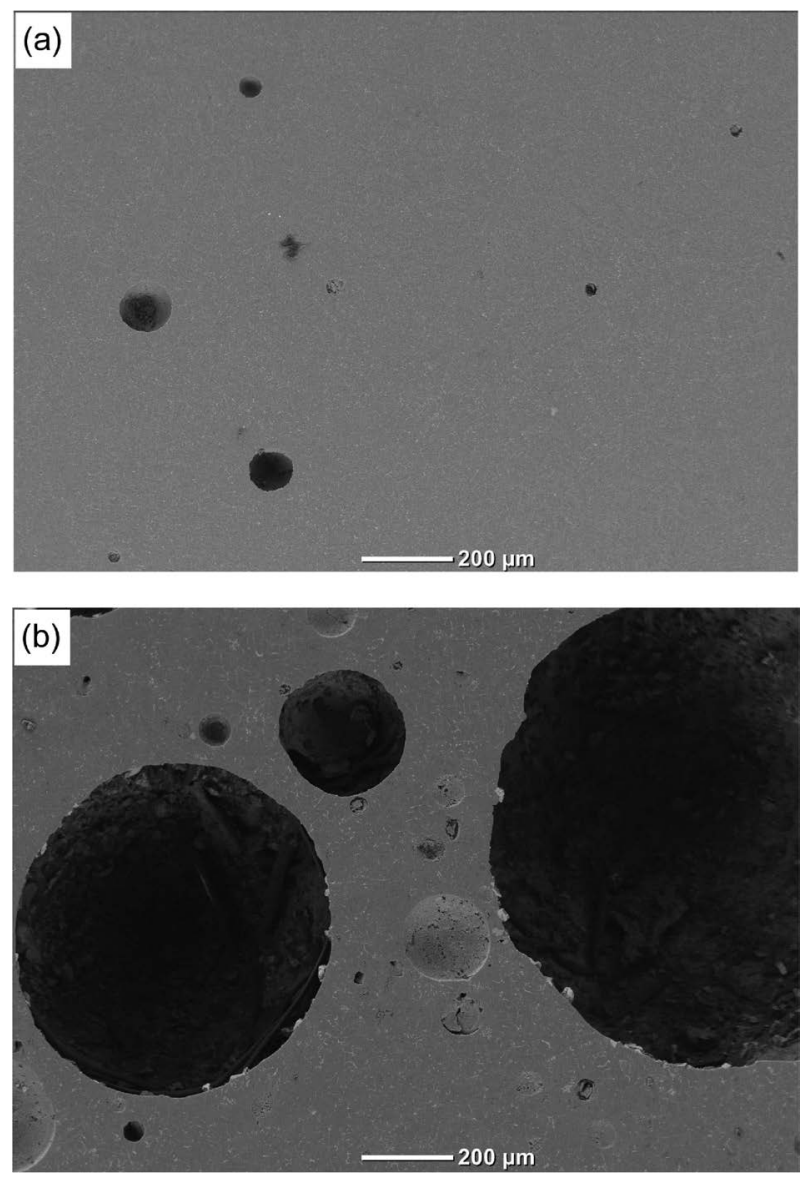

Fig. 5 SEM (BEI) micrographs of the cross section area of the Normal foams. (a) corresponds to $x=5 \mathrm{~mm}$ and (b) corresponds to $x=55 \mathrm{~mm}$.

いほど白く見える．濃い灰色の領域は ADC12アルミニウム合 金，黒い円形の領域は気孔打よび気孔の縁に白く見える粒子 が発泡剂粒子である. $x=5 \mathrm{~mm}$ の Normal プリカーサは $x=$ $55 \mathrm{~mm}$ の Normal プリカーサと比較して気孔が少なかった $x=$ $5 \mathrm{~mm}$ および $x=55 \mathrm{~mm}$ の Normal プリカーサのどちらも, 発 泡剂粒子は気泡の内壁に存在して打り，七ル壁内部にはほと んど存在しなかった.

PALC 試験片に関しては, $n_{\mathrm{Al}} \geqq 1.5$ mass\%では粘性が高す
ぎて金型に注湯することができず，本研究の実験条件におい てはプリカーサを作製できなかった.

\section{2 発泡体}

Normal 発泡体の気孔率を Fig. 4 に示す。底部から $20 \mathrm{~mm}$ までの気孔率は $10 \%$ 未满と低いが, $20 \mathrm{~mm}$ 以降はお抄むね 60\%以上の気孔率となった. Normal 試験片の気孔率が低い領 域と高い領域は発泡試験前後で一致した。

アルミニウム溶湯中の $\mathrm{TiH}_{2}$ の熱分解に関しては, Yang ら ${ }^{26)}$ により熱分解反応速度式を用いた解析が行われており, 温度 が高いほど早く分解することが報告されている. Yang らの解 析によれば $933 \mathrm{~K}$ のアルミニウム溶湯中であっても, $60 \mathrm{~s}$ 保 持して分解する $\mathrm{TiH}_{2}$ は約 $55 \%$ である. 本研究に扔けるプリ

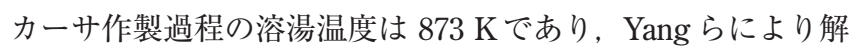
析された溶湯温度と比較してさらに低く, $\mathrm{TiH}_{2}$ が添加量の $55 \%$ を超えて分解したとは考えにくい. $55 \%$ の $\mathrm{TiH}_{2}$ が分解済 みであったとしても, 単純計算で 0.68 mass\%の未分解 $\mathrm{TiH}_{2}$ がプリカーサ内部に残留していることになる。 プリカーサは $\mathrm{TiH}_{2}$ が 0.6 mass\%含有していれば十分に発泡することが知ら れている ${ }^{27,28)}$. また, Saito ら ${ }^{29)}$ は, 本研究の溶湯温度より高 い $908 \mathrm{~K}$ に加熱した固液共存状態の A2024アルミニウム合金 に, $\mathrm{TiH}_{2}$ 粉末を 1 mass\%添加して $100 \mathrm{~s}$ 攪拌後冷却すること で作製したプリカーサを $943 \mathrm{~K}$ に加熱することで, 投影面積 で 3 倍に膨張することを報告している．金型底部から $20 \mathrm{~mm}$ までの試験片が発泡しなかった原因が $\mathrm{TiH}_{2}$ の消耗とは考えに くい.

液相線温度に近い $873 \mathrm{~K}$ の溶湯を室温の銅製金型に注湯し ているので, 溶湯は注湯後すぐに凝固すると考えられる. 注 湯後に $\mathrm{TiH}_{2}$ が上部に移動することは困難である。 また, Normal, $\mathrm{PAlC}, \mathrm{Al}_{2} \mathrm{O}_{3} \mathrm{C}$ および $\mathrm{TiH}_{2} \mathrm{C}$ プリカーサを作製過程にお いて, 溶湯を诗堝から金型に注湯する際, 流動性の高い溶湯 が金型に流れ込んだ後, 遅れて流動性の低い溶湯が金型に流 れ込む様子が観察されている.

したがって, 金型底部から $20 \mathrm{~mm}$ までの試験片がほとんど 発泡しなかった原因は, 発泡剂添加後の溶湯の攪找が不十分 であり, $\mathrm{TiH}_{2}$ 粒子が金型底部近傍のプリカーサにほとんど含 まれていなかったためと考えられる.

$\mathrm{ADC} 12$ のように $\mathrm{TiH}_{2}$ の分解温度に対して液相線温度が低い 合金であれば, $933 \mathrm{~K}$ 以下の温度の液相または固液共存状態 で, $\mathrm{TiH}_{2}$ 粉末を添加して $60 \mathrm{~s}$ 程度の短い時間の攪挥を行うこ とで, 鋳造プリカーサ法により気孔率 $60 \%$ 以上の発泡体を得 ることは可能である. 純アルミニウムに近い化学組成を有す る液相線温度が高い合金の場合には, プリカーサ作製過程に 㧍ける $\mathrm{TiH}_{2}$ 粉末の消耗が大になるので, 高気孔率発泡体を作 製するためには分解温度の高い発泡凨の利用を検討する必要 がある.

Normal 発泡体のセル形態観察結果を Fig. 6 に示す. Fig. 6 に対応する Normal 発泡体の平均気孔径, 最大気孔径および 気孔径の標準偏差を Table 2 にまとめる. 低気孔率であった $x=5 \mathrm{~mm}$ の Normal 発泡体では, 小さな気孔がわずかに上部 だけに存在しており， $x=25 \mathrm{~mm}, 65 \mathrm{~mm}$ 抢よび $95 \mathrm{~mm}$ の Normal 発泡体では, 気孔は比較的均一に分布していた， $x$ の 
(a)

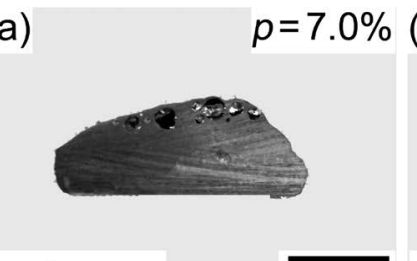

$x=5 \mathrm{~mm}$
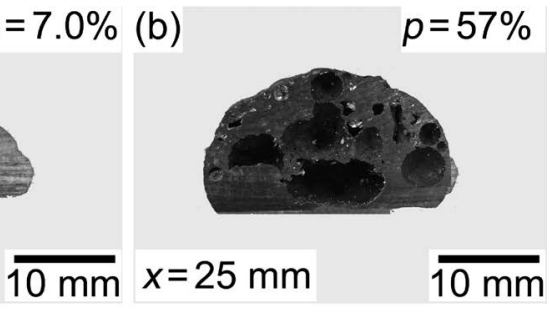

(c)

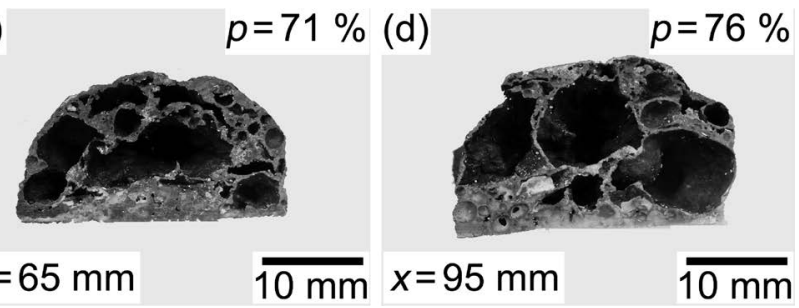

Fig. 6 Cross section area of the Normal foams with different positions.

Table 2 Mean pore diameter, maximum pore diameter and a standard deviation of the Normal foams in Fig. 6.

\begin{tabular}{cccc}
\hline $\begin{array}{c}x \\
\mathrm{~mm}\end{array}$ & $\begin{array}{c}d_{\mathrm{m}} \\
\mathrm{mm}\end{array}$ & $\begin{array}{c}d_{\max } \\
\mathrm{mm}\end{array}$ & $\sigma_{\mathrm{p}}$ \\
\hline 5 & 1.3 & 2.1 & 0.47 \\
25 & 2.5 & 6.7 & 1.8 \\
65 & 2.2 & 12 & 2.3 \\
95 & 2.9 & 11 & 3.1 \\
\hline
\end{tabular}

増加に伴い気孔率は増加したが平均気孔径はほとんど変わら なかった. $x=65 \mathrm{~mm}$ および $95 \mathrm{~mm}$ の Normal 発泡体に関し ては最大気孔径が平均気孔径の5.4倍および3.7倍であり，一部 の気孔が粗大化していた，気孔径の標準偏差 $\sigma_{\mathrm{p}}$ は $x$ の増加に 伴い単調増加しており, 気孔率の高い Normal 発泡体では気 孔径のばらつきが大きかった，高気孔率かつ気孔径の均一な 気孔が一様に分布する発泡体を得るためには, 増粘剤の増加 や変更または半凝固状態30)の利用などにより発泡過程のマト リックスの粘度を増加させる必要がある.

PAlC 発泡体の最大気孔率㧍よび平均気孔率を純アルミニウ 厶添加量 $n_{\mathrm{Al}}$ に対して Fig. 7 に示す. $n_{\mathrm{Al}}=1.0$ mass\%の平均 気孔率および最大気孔率はそれぞれ $61 \%$ および78\%であった。

楊ら ${ }^{22,23)}$ は平均粒子径 $d_{\mathrm{Al}}=60 \mu \mathrm{m}$ の純アルミニウム粉末 5 mass\%を $903 \mathrm{~K}$ で AC4C 合金溶湯に添加して，大気中で 600 rpm で 20 min 攪挥することで, 純アルミニウム粉末表面の酸 化物の破壞と分散拉よび溶湯の酸化により溶湯の増粘を行い, 攪拌トルクが同攪拌条件の純アルミニウム粉末無添加の溶湯 の約1.2倍，攪拌前の約1.7倍になることを確認している．粒子 が分散した溶湯をニュートン流体と仮定した場合，見かけの 粘度 $\eta^{\prime}$ と攪挥トルク $N$ には次式の関係があることが実験的 に知られており ${ }^{31)}$ ，攪拌トルクの増加は見かけ粘度の増加に 対応している.

$$
\eta^{\prime}=\frac{\alpha N\left(1-\beta^{2}\right)}{4 \pi r^{2} L \Omega}
$$

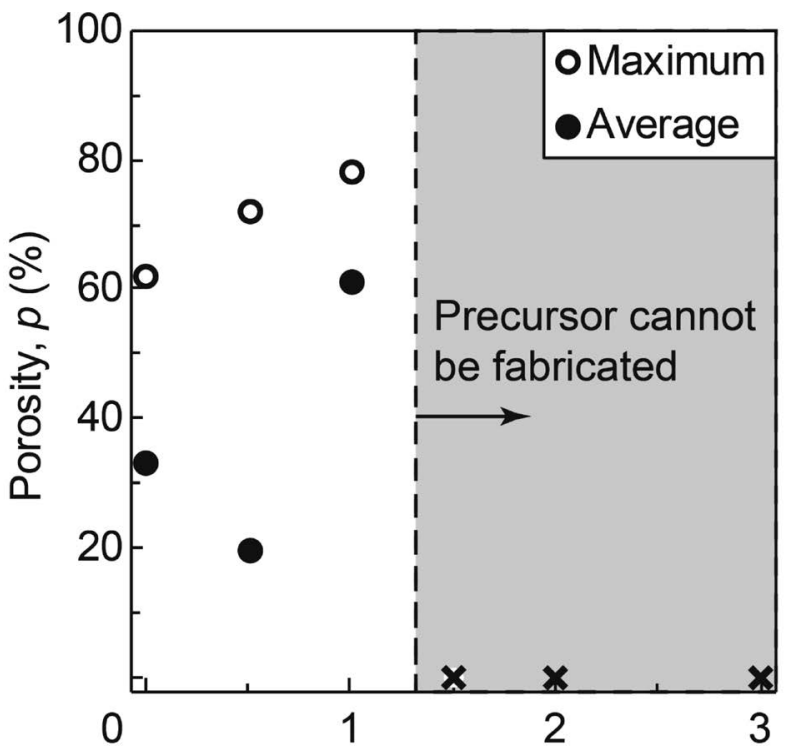

Additive amount of Al powder, $n_{\mathrm{Al}}$ (mass $\%$ )

Fig. 7 Porosity plotted as a function of additive amount of $\mathrm{Al}$ powder.

ここで, $\alpha$ は補正倸数， $\beta$ は坩堝径と攪拌プロペラ径の比, $r$ は攪拌プロペラの半径および $L$ は攪汼プロペラの浸漬深さで ある。本研究では攪拌トルクを計測していないため, 純アル ミニウム粉末添加による溶湯粘度の上昇を定量的に議論する ことはできないが，純アルミニウム粉末添加による気孔率の 増加押よび純アルミニウム粉末を 1.5 mass \%以上添加すると 溶湯の粘性が高すぎて溶湯を金型に注湯することができな かったことから，本研究でも純アルミニウム粉末の添加によ り溶湯の粘度は上昇したと考えられる。

本研究で用いた純アルミニウム粉末の粒子径は約 $3 \mu \mathrm{m}$ で あり，楊らの用いた平均粒子径 $60 \mu \mathrm{m}$ の粉末と比べて約 20 分 の 1 である，実際には，粉末粒子表面の酸化物厚さは粉末製 造方法や前処理などにより異なるが，両粉末を粒子表面が厚 さ $100 \AA^{32}$ の酸化物 $\left(\mathrm{Al}_{2} \mathrm{O}_{3}\right)$ に覆われた球状粒子と仮定し, 粒 子表面の酸化物が全て溶湯に分散したと考えた場合の酸化物 体積率の増加を計算した結果を純アルミニウム粉末の添加量 の関数として Fig. 8 に示す. $3 \mu \mathrm{m}$ の純アルミニウム粉末を 1 mass\%添加した場合の酸化物の増加は, $60 \mu \mathrm{m}$ の純アルミニ ウム粉末を 5 mass\%添加した場合と比べ約 3.4 倍である．楊 ら ${ }^{22)}$ の研究では純アルミニウム粉末を $\mathrm{AC} 4 \mathrm{C}$ 溶湯に添加して から $20 \mathrm{~min}$ 大気中で攪拌することで，溶湯中の酸化物の量が 4.6 vol.\%になることが確認されている，純アルミニウム表面 の酸化物量と攪拌後の酸化物量が比例するのであれば，式 （6）に示す Elinstein ${ }^{22)}$ の式より, 本研究の溶湯粘度は, 純了 ルミニウム粉末添加および攪拌前の1.4倍程度増加したことに なる。

$$
\eta^{\prime}=\eta_{0}\left(1+2.5 V_{\mathrm{c}}\right)
$$

しかしながら， 1 mass\%純アルミニウム粉末を添加した場 合に粒子表面の酸化物の破壊・分散による溶湯内部の酸化物 の増加は約 2.0 vol. ppm と小さく, 粒子表面の酸化物の破 壞・分散のみによる増粘効果は大きくないと考えられる.

楊ら ${ }^{22)}$ は，溶湯の見かけ密度の増加は溶湯中の酸化物粒子 


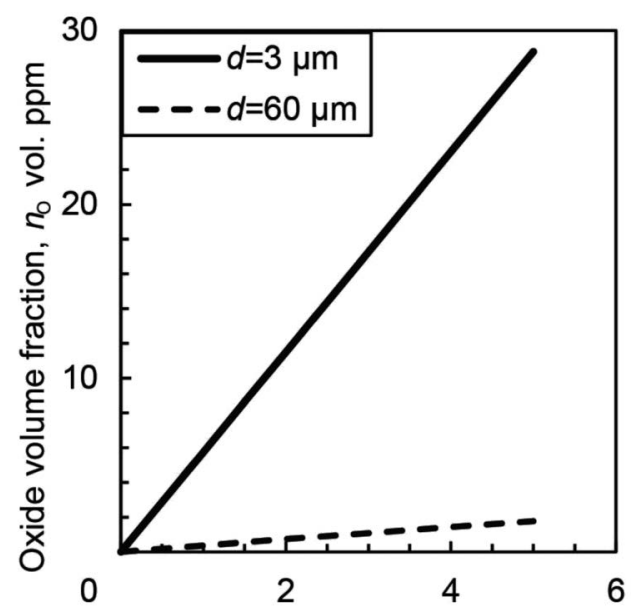

Additional amount of $\mathrm{Al}$ powder , $n_{\mathrm{Al}}$ mass $\%$

Fig. 8 Increase of oxide volume fraction by pure $\mathrm{Al}$ powder addition.
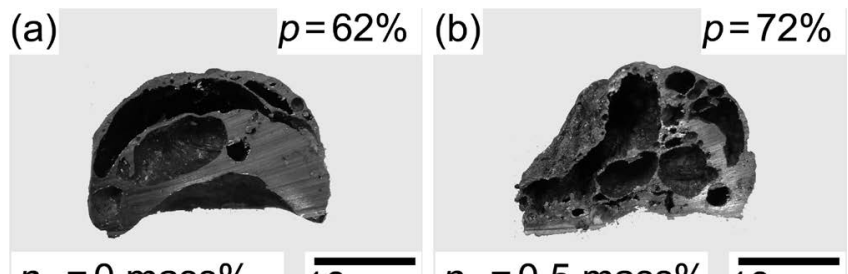

$n_{\mathrm{Al}}=0$ mass $\% \quad \overline{10 \mathrm{~mm}} n_{\mathrm{Al}}=0.5$ mass $\% \overline{10 \mathrm{~mm}}$ (c) $\quad p=78 \%$

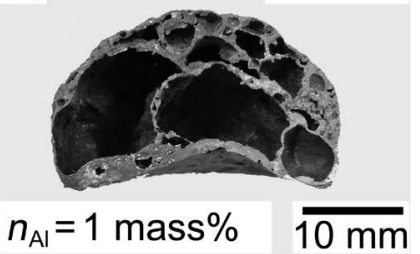

Fig. 9 Cross section area of the PAlC foams with different pure Al powder amount.

の体積増加だけでは説明できず，Zettlemoyer と Lower が提 案した次式のように粒子表面積を考慮すべきとしている.

$$
\eta^{\prime}=\eta_{0}\left[\mathrm{~K}_{1}+\left(1+\mathrm{K}_{2} A\right) V_{\mathrm{c}}\right]
$$

ここで, $\eta_{0}$ は元の粘度, $V_{\mathrm{c}}$ は粒子体積率, $A$ は粒子の表面積, $\mathrm{K}_{1}$ および $\mathrm{K}_{2}$ は物質定数である. 溶湯の粘性におよぼす酸化物 粒子の表面積の影響や攪挥による溶湯の酸化の影響について も今後実験的に検討する必要がある.

$\mathrm{ADC} 12$ アルミニウムに含有される $\mathrm{Si}$ を $10.8 \mathrm{mass} \%$ と考え れば, 純アルミニウム粉末を 3 mass \% 添加しても液相線温度

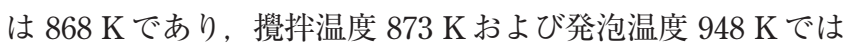
液相状態のため半凝固による粘度上昇は生じない。 また, 純 アルミニウム粉末を 3 mass \%添加しても, 液相線温度の上昇 は約 $3 \mathrm{~K}$ であり, 液相線温度上昇による粘度の上昇もほとん ど生じないと考えられる。

PAlC 発泡体のセル形態観察結果を Fig. 9 に示す. Fig. 9 に 対応する PAIC 発泡体の平均気孔径, 最大気孔径および気孔 径の標準偏差を Table 3 にまとめる．純アルミニウム粉末を 一番多く添加した $n_{\mathrm{Al}}=1$ mass $\%$ の $\mathrm{PAlC}$ 発泡体は, $d_{\max }=11$ $\mathrm{mm}$ と $\mathrm{PAlC}$ 発泡体の中で最大気孔径が最も大きく, 平均気
Table 3 Mean pore diameter, maximum pore diameter and a standard deviation of the PAlC foams in Fig. 9.

\begin{tabular}{cccc}
\hline $\begin{array}{c}n_{\mathrm{Al}} \\
\operatorname{mass} \%\end{array}$ & $\begin{array}{c}d_{\mathrm{m}} \\
\mathrm{mm}\end{array}$ & $\begin{array}{c}d_{\max } \\
\mathrm{mm}\end{array}$ & $\sigma_{\mathrm{p}}$ \\
\hline 0 & 3.4 & 8.9 & 2.9 \\
0.5 & 2.4 & 8.6 & 2.1 \\
1 & 3.2 & 11 & 2.9 \\
\hline
\end{tabular}

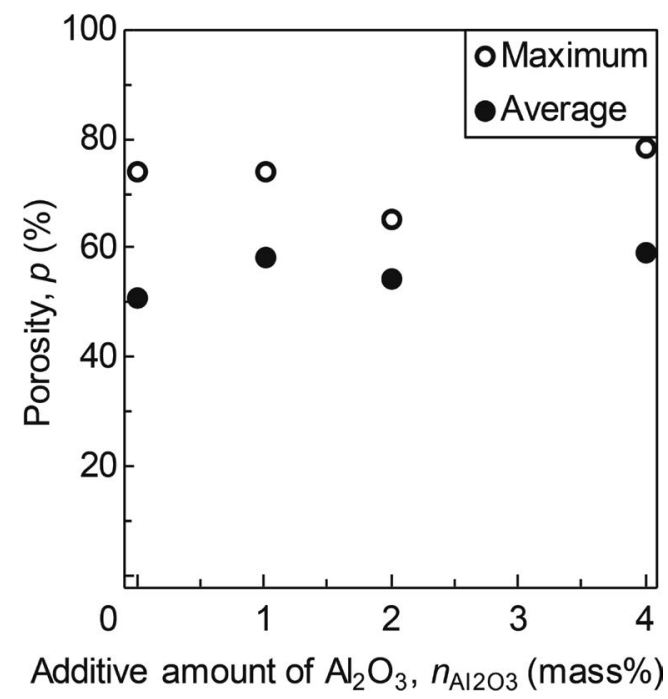

Fig. 10 Porosity plotted as a function of additive amount of $\mathrm{Al}_{2} \mathrm{O}_{3}$ powder.

孔径も $n_{\mathrm{Al}}=0.5$ mass $\%$ の PAlC 発泡体より大きかった. 気孔 径の標準偏差に関して, $n_{\mathrm{Al}}=0.5$ mass\%の PAlC 発泡体は $n_{\mathrm{Al}}=0$ mass $\%$ おび 1 mass $\%$ の PAlC 発泡体と比較して小さ いが, $n_{\mathrm{Al}}=0$ mass \% と 1 mass\%の PAlC 発泡体の気孔径の標 準偏差は同じであった，純アルミニウムを増粘剤として添加 することにより最大気孔率は増加したが，気孔は一部が粗大 化し, 気孔径のばらつきも小さくならなかった。画像解析で 検出された $n_{\mathrm{Al}}=0.5$ mass \%および 1 mass $\%$ の PAlC 発泡体の 気孔の数は $n_{\mathrm{Al}}=0$ mass $\%$ の PAlC 発泡体の 2 倍以上であった. 純アルミニウムの添加によりマトリックス粘度が上昇し, 発 泡過程において溶融したマトリックスが水素ガスを保持する ことが可能になり, マトリックス外部への水素ガス流出が抑 制されたためと考えられる.

$\mathrm{Al}_{2} \mathrm{O}_{3} \mathrm{C}$ 発泡体の最大気孔率および平均気孔率を $\mathrm{Al}_{2} \mathrm{O}_{3}$ 粉末 添加量 $n_{\mathrm{Al} 2 \mathrm{O} 3}$ に対して Fig. 10 に示す. $\mathrm{Al}_{2} \mathrm{O}_{3}$ 粉末を添加しても 平均気孔率および最大気孔率はほとんど変化しなかった。

粉末法に関しては $0.2 \sim 0.8$ mass\%の $\mathrm{Al}_{2} \mathrm{O}_{3}$ 粉末の添加で, プリカーサが最も膨張するという報告がある ${ }^{33)}$. 一方で, 半 谷ら ${ }^{34)}$ は FSP 法を用いて作製した試験片に関して, $\mathrm{Al}_{2} \mathrm{O}_{3}$ 粉 末を 10 mass \% 添加することで最大気孔率を得たと報告して いる. 粉末法の場合, 素材粉末表面の酸化被膜が多くプリ カーサ内部に取り込まれ増粘剤として作用するが, 板材を素 材として用いる FSP 法ではプリカーサに取り込まれる素材表 面の酸化被膜が少ないので, 気孔安定化のために $\mathrm{Al}_{2} \mathrm{O}_{3}$ 粉末 をより多く必要としたと考えられる. ポーラスアルミニウム 作製に鋳造を用いる場合, 粒子径約 $1 \mu \mathrm{m}$ の $\mathrm{Al}_{2} \mathrm{O}_{3}$ 粉末を用い 
て増粘効果を得ようとするのであれば， 5 ～10 vol.\% 程度 ${ }^{35)}$ 溶湯に添加する必要がある. 本研究では, $\mathrm{Al}_{2} \mathrm{O}_{3}$ 粉末添加量が 少なかったことが $\mathrm{Al}_{2} \mathrm{O}_{3}$ 粉末添加による気孔率増加がほとん ど見られなかった原因の一つと考えられる.

$\mathrm{Al}_{2} \mathrm{O}_{3} \mathrm{C}$ 発泡体のセル形態観察結果を Fig. 11 に示す. Fig. 11 に対応する $\mathrm{Al}_{2} \mathrm{O}_{3} \mathrm{C}$ 発泡体の平均気孔径, 最大気孔径およ び気孔径の標準偏差を Table 4 にまとめる. $n_{\mathrm{Al} 2 \mathrm{O} 3}=1$ mass $\%$ の $\mathrm{Al}_{2} \mathrm{O}_{3}$ 発泡体を除き, 平均気孔径および最大気孔径は気孔 率に対応しており, 気孔径の標準偏差は $\mathrm{Al}_{2} \mathrm{O}_{3}$ 粒子を添加し た方が小さくなる傾向があった. $\mathrm{Al}_{2} \mathrm{O}_{3}$ 粒子は発泡過程におい て気孔の合体成長を抑制し, 気孔の安定化に寄与したと考え られる. $\mathrm{Al}_{2} \mathrm{O}_{3}$ 粉末を添加した発泡体のセル壁の一部に凝集し た $\mathrm{Al}_{2} \mathrm{O}_{3}$ 粒子とみられる白い領域が観察された. 特に $n_{\mathrm{A} 12 \mathrm{O} 3}=$ 4 mass\%の $\mathrm{Al}_{2} \mathrm{O}_{3} \mathrm{C}$ 発泡体ではこの白い領域が多く観察され た. $\mathrm{Al}_{2} \mathrm{O}_{3}$ 粒子が均一に分散しなかったことも, $\mathrm{Al}_{2} \mathrm{O}_{3}$ 粉末添 加による気孔率増加がみられなかった一因と考えられる. 微 細セラミックス粒子をアルミニウム溶湯に十分に摫拌するこ とは難しいので 17,20$)$, 微細セラミックス粒子を増粘剤として 利用する場合は攪拌方法について検討を要する.

$\mathrm{TiH}_{2} \mathrm{C}$ 発泡体の平均気孔率を $\mathrm{TiH}_{2}$ 粉末の熱処理温度に対し て Fig. 12 に示す. 熱処理なしの発泡体についても熱処理温度 $300 \mathrm{~K}$ にプロットした. 熱処理温度の上昇に伴い発泡前気孔 率は低下したが, 発泡後気孔率も低下した。発泡後試験片の 断面写真を Fig. 13 に示す. Fig. 13 に対応する $\mathrm{TiH}_{2} \mathrm{C}$ 発泡体 の平均気孔径, 最大気孔径および気孔径の標準偏差を Table 5 にまとめる。熱処理なしおよび $773 \mathrm{~K} て ゙$ 熱処理を施した (a)

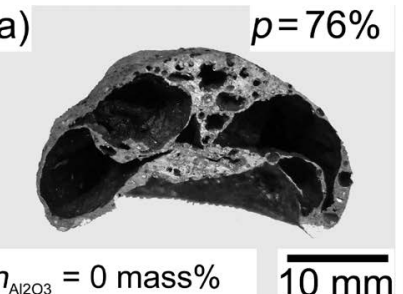

$n_{\mathrm{A} 1203}=0$ mass $\%$

(c) $p=67 \%$

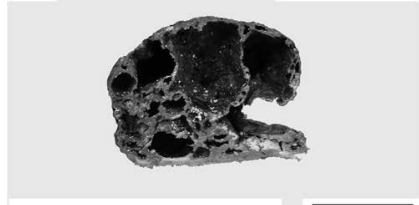

(b)

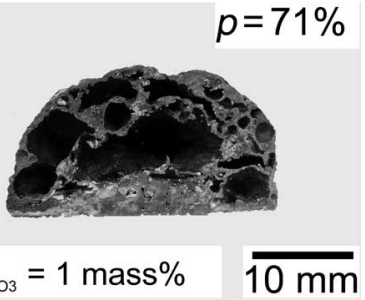

(d)

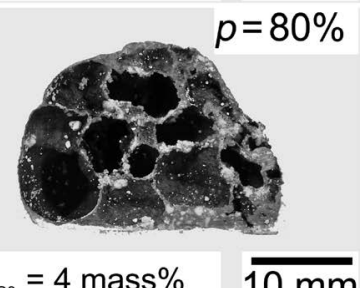

$n_{\mathrm{A} 1203}=2$ mass $\% \quad \overline{10 \mathrm{~mm}} n_{\mathrm{A} 1203}=4$ mass $\% \quad \overline{10 \mathrm{~mm}}$

Fig. 11 Cross section area of the $\mathrm{Al}_{2} \mathrm{O}_{3} \mathrm{C}$ foams with different $\mathrm{Al}_{2} \mathrm{O}_{3}$ powder amount. Fig. 6 (c) is reprinted as Fig. 11 (b).

Table 4 Mean pore diameter, maximum pore diameter and a standard deviation of the $\mathrm{Al}_{2} \mathrm{O}_{3} \mathrm{C}$ foams in Fig. 11 .

\begin{tabular}{cccc}
\hline $\begin{array}{c}n_{\mathrm{Al} 2 \mathrm{O} 3} \\
\text { mass } \%\end{array}$ & $\begin{array}{c}d_{\mathrm{m}} \\
\mathrm{mm}\end{array}$ & $\begin{array}{c}d_{\max } \\
\mathrm{mm}\end{array}$ & $\sigma_{\mathrm{p}}$ \\
\hline 0 & 3.5 & 8.8 & 2.9 \\
1 & 2.2 & 12 & 2.3 \\
2 & 2.7 & 8.3 & 2.1 \\
4 & 3.7 & 9.3 & 2.2 \\
\hline
\end{tabular}

$\mathrm{TiH}_{2}$ 粉末を用いて得られた $\mathrm{TiH}_{2} \mathrm{C}$ 発泡体の最大気孔径はどち らも $12 \mathrm{~mm}$ であり一部の気孔が粗大化していた. $823 \mathrm{~K} て ゙$ 熱 処理した $\mathrm{TiH}_{2}$ 粉末を用いて得られた $\mathrm{TiH}_{2} \mathrm{C}$ 発泡体において は, 最大気孔率が平均気孔率の 2.2 倍程度であり, 気孔径の標 準偏差も 1.3 と $\mathrm{TiH}_{2} \mathrm{C}$ 発泡体中最小となっており, 微細な気孔 が一様に分布していた。 これは， $\mathrm{TiH}_{2}$ が熱処理中に分解して おり，発泡過程で気孔が十分に膨張するには，水素ガス圧が 不足していたためである. 適切な熱処理を施した $\mathrm{TiH}_{2}$ 粉末を 用いると熱処理を施してない $\mathrm{TiH}_{2}$ 粉末を用いるより気孔率が 増加することが知られている ${ }^{15)}$. 本研究で用いた試験条件は

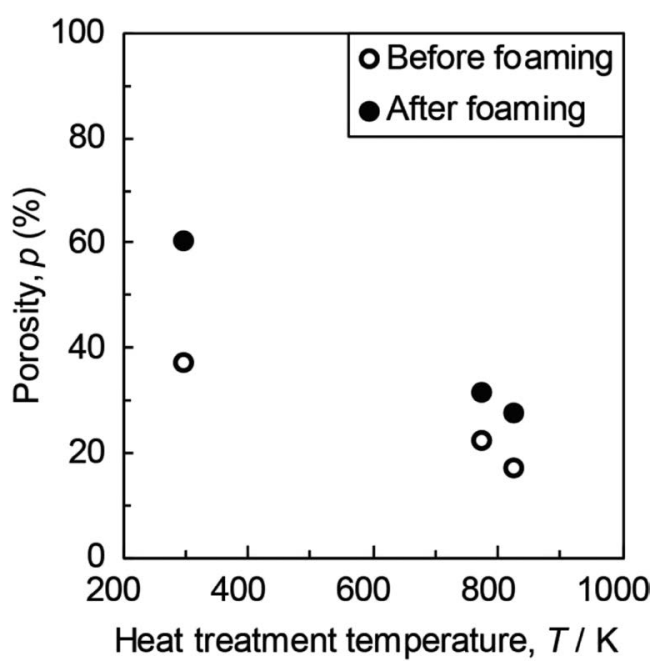

Fig. 12 Average porosity plotted as a function of heat treatment temperature of $\mathrm{TiH}_{2}$. (a)

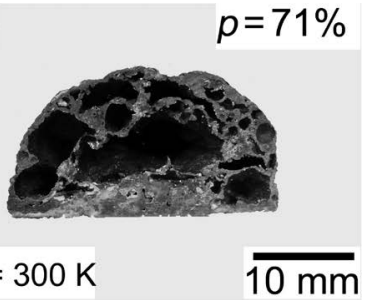

(b)

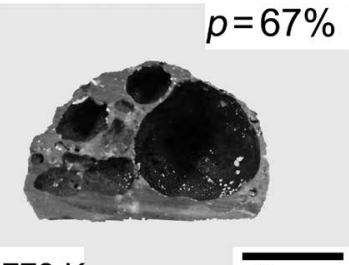

(c)

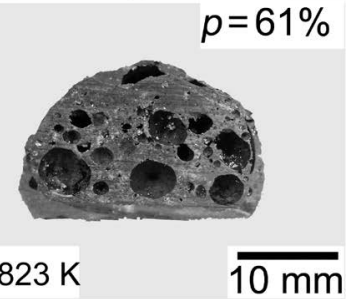

Fig. 13 Cross section area of the foam with different heat treatment temperature of $\mathrm{TiH}_{2}$. Fig. 6 (c) is reprinted as Fig. 13 (a).

Table 5 Mean pore diameter, maximum pore diameter and a standard deviation of the $\mathrm{TiH}_{2} \mathrm{C}$ foams in Fig. 13 .

\begin{tabular}{cccc}
\hline $\begin{array}{c}T \\
\mathrm{~K}\end{array}$ & $\begin{array}{c}d_{\mathrm{m}} \\
\mathrm{mm}\end{array}$ & $\begin{array}{c}d_{\max } \\
\mathrm{mm}\end{array}$ & $\sigma_{\mathrm{p}}$ \\
\hline 300 & 2.2 & 12 & 2.3 \\
773 & 3.9 & 12 & 3.1 \\
823 & 2.1 & 4.7 & 1.3 \\
\hline
\end{tabular}


熱処理時間が長すぎた可能性がある. $\mathrm{TiH}_{2}$ 粉末に適切な熱処 理を施せば，発泡前気孔率を低下させ，発泡後気孔率を増加 させることができると考えられる。しかしながら，熱処理を 施した $\mathrm{TiH}_{2}$ 粉末を発泡剂として利用するとポーラスアルミニ ウム作製コストが増加する。鋳造プリカーサ法は安価にポー ラスアルミニウムを作製することをコンセプトとしている. 本研究では一般的に用いられている発泡剂である $\mathrm{TiH}_{2}$ 粉末を 発泡剂として用いたが, 鋳造プリカーサ法に用いる発泡剂と しては熱处理を施した $\mathrm{TiH}_{2}$ 粉末より, 分解温度が高く安価な $\mathrm{CaCO}_{3}$ 粉末などの利用を検討すべきである ${ }^{36,37)}$.

本研究に扔いて，ADC12アルミニウム合金に 1 mass\%の純 アルミニウム粉末, 1 mass \%の $\mathrm{Al}_{2} \mathrm{O}_{3}$ 粉末および 1.5 mass\% の $\mathrm{TiH}_{2}$ 粉末を添加することにより, 鋳造プリカーサ法を用い て製作したプリカーサを発泡させることにより, 最大気孔率 約 $80 \%$ の発泡体を得ることができた。 しかしながら，プリ カーサ作製過程で発泡剤が分解するためプリカーサの気孔率 が高いので，プリカーサ作製過程に扔ける発泡剤の分解を抑 制する必要がある。

\section{3 力学的特性の評価}

Normal 発泡体より切り出した圧縮試験片の断面観察写真を Fig. 14 に示す. Fig. 14 に対応する圧縮試験片の平均気孔径, 最大気孔径拧よび気孔径の標準偏差を Table 6 にまとめる. 本 研究で作製した Normal 発泡体の平均気孔径および標準偏差 はALPORAS とほとんど変わらなかった，最大気孔径は Nor$\mathrm{mal}$ 発泡体の方が $2.3 \mathrm{~mm}$ 大きかった。発泡過程に扔けるマ トリックスの粘性が低かったため, 本研究で作製した圧縮試 験片も一部の気孔が粗大化していた。压縮試験に用いた ALPORAS 打よびNormal 発泡体の気孔率はそれぞれ約 $80 \%$ お よび55\%である。これらのポーラスアルミニウムの圧縮応力 一ひずみ線図を Fig. 15 に示す. Normal 発泡体には明確な初 期最大圧縮応力 ${ }^{6}$ が存在し, 初期最大圧縮応力は約 $30 \mathrm{MPa}$ で あった. Normal 発泡体のプラトー応力 $\left.{ }^{6}\right)$ は約 $20 \mathrm{MPa}$ であり, プラトー領域に扔いて荷重の上下を繰り返す挙動が確認され た.一方, ALPORASには明確な初期圧縮応力は確認できな い. ALPORAS のプラトー応力は約 $2 \mathrm{MPa}$ であり, プラトー 領域において荷重の上下を繰り返す挙動は確認できなかった. Normal 発泡体の初期最大圧縮応力およびプラトー応力は ALPORAS と比較して大きかった.これは, 圧縮試験に用い た Normal 発泡体の気孔率が ALPORAS に比較して低いこと および, ALPORAS のマトリックスが純アルミニウムなのに 対し, Normal 発泡体のマトリックスが ADC12アルミニウム 合金であったためである.Normal 発泡体の圧縮挙動は延性的

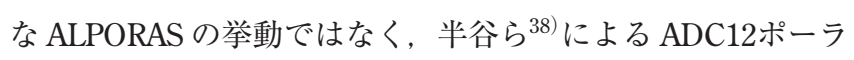
スアルミニウム抄よびALCAN 製ポーラスアルミニウム $(\mathrm{ALCAN})^{39)}$ の脆性的な挙動と抢打むね一致している. 半谷 ら ${ }^{38,40)}$ が作製した $p=40 \%$ および $70.8 \%$ の $\mathrm{ADC} 12$ ポーラスア ルミニウムの初期圧縮応力はそれぞれ約 $45 \mathrm{MPa}$ および 26 MPa であった. Normal 発泡体の気孔率打よび初期圧縮応力 はどちらも半谷らの $\mathrm{ADC} 12$ ポーラスアルミニウムの中間程度 であり, 鋳造プリカーサ法を用いて既存の研究と遜色ない強 度を有するポーラスアルミニウムを作製できた。 (a)

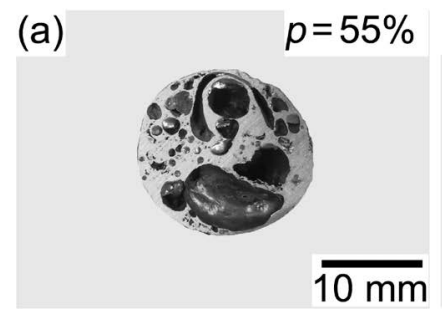

(b) $p=83 \%$

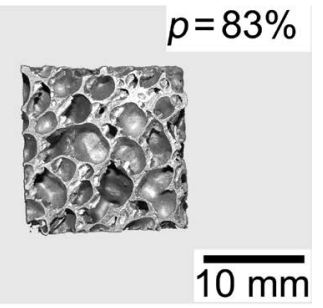

Fig. 14 Specimens of the compressive test.

Table 6 Mean pore diameter, maximum pore diameter and a standard deviation of the TC foams in Fig. 14.

\begin{tabular}{cccc}
\hline Specimen & $\begin{array}{c}d_{\mathrm{m}} \\
\mathrm{mm}\end{array}$ & $\begin{array}{c}d_{\max } \\
\mathrm{mm}\end{array}$ & $\sigma_{\mathrm{p}}$ \\
\hline Present & 2.3 & 7.9 & 1.8 \\
ALPORAS & 2.0 & 5.6 & 1.1 \\
\hline
\end{tabular}

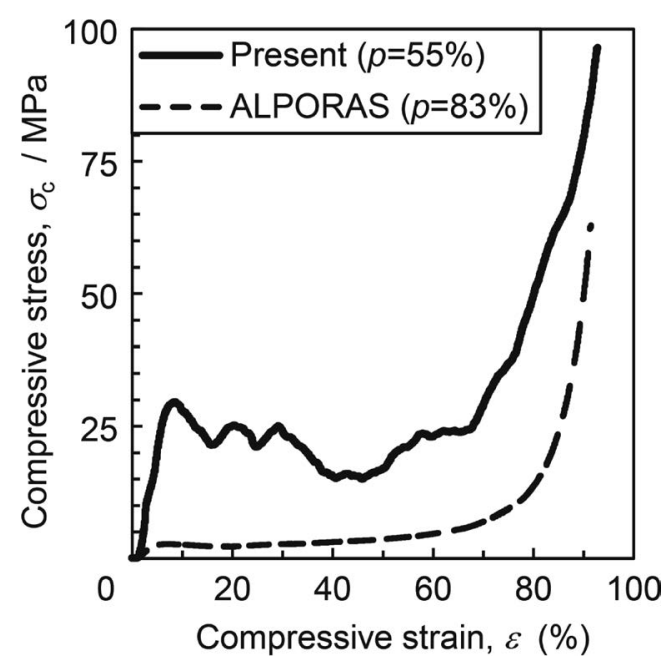

Fig. 15 Compressive stress strain curve.

鋳造プリカーサ法を用いて市販品と同程度の気孔率を有す るポーラスアルミニウムを作製することができ, 既存の研究 と同様な圧縮挙動を示した。 セル形態制御に課題は残るもの の, 鋳造プリカーサ法を用いてポーラスアルミニウムをより 安価に作製できる可能性が示唆された.

4. 結論

本研究では複雑形状の大型アルミニウムを比較的安価に作 製する方法として，プリカーサ作製に鋳造を利用した鋳造プ リカーサ法を提案し，その有効性について検討を行った。 そ の結果, 次の結論が得られた。

（1）鋳造プリカーサ法を用いて本研究で作製した $\mathrm{ADC1}$ 労 ルミニウム合金に 1 mass\%の純アルミニウム粉末， 1 mass\% の $\mathrm{Al}_{2} \mathrm{O}_{3}$ 粉末および 1.5 mass\%の $\mathrm{TiH}_{2}$ 粉末を添加したポーラ スアルミニウムの最大気孔率は $80 \%$ であった. 鋳造プリカー サ法を用いて市販のポーラスアルミニウムと同等の気孔率を 有するポーラスアルミニウムを作製することは可能である.

（2）鋳造プリカーサ法を用いて作製した $\mathrm{ADC} 12$ アルミニウ 
ム合金に 1 mass\%の純アルミニウム粉末, 1 mass \%の $\mathrm{Al}_{2} \mathrm{O}_{3}$ 粉末および 1.5 mass\%の $\mathrm{TiH}_{2}$ 粉末を添加したプリカーサは約 $40 \%$ の気孔率を有していた. $\mathrm{TiH}_{2}$ 粉末の熱処理による分解温 度の上昇はプリカーサ気孔率の低下には有効ではなかった。 発泡過程で大きく膨張させるために低気孔率プリカーサを得 るためには, $\mathrm{TiH}_{2}$ 粉末より高温で分解する発泡剂の利用につ いて検討する必要がある。

（3）鋳造プリカーサ法により得られたプリカーサの発泡過 程における気孔安定化の方法として, プリカーサ製作過程に

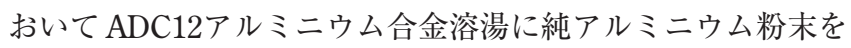
添加することにより，プリカーサマトリックスの粘度上昇を 試みた. 純アルミニウム粉末添加量 1 mass \%まで添加量増加 に伴い, 得られるポーラスアルミニウムの気孔率は $80 \%$ まで 増加した. 純アルミニウム粉末を添加することで水素ガスを 溶湯中に多く保持することが可能である. しかしながら, 純 アルミニウム粉末を 1 mass \% 添加しても一部の気孔は粗大化 し, 気孔径のばらつきも純アルミニウム粉末を添加していな い発泡体と変わらなかった。

(4) 本研究において, $\mathrm{Al}_{2} \mathrm{O}_{3}$ 粉末の添加により気孔径のばら つきが小さくなる傾向を示したが気孔径および気孔率はほと んど増加しなかった，微細セラミックス粒子添加によるプリ カーサマトリックスの増粘は, 発泡過程の気孔安定化のため に，一般的なプリカーサ法で用いられており気孔率の増加と 気孔径の減少に寄与することが知られている.しかしながら, 鋳造プリカーサ法においては, 添加量が少なくまた作製過程 で均一に攪拌することができなかったため, 発泡過程におけ る気孔安定化における寄与は限定的であった。鋳造プリカー サ法において, 増粘剤として微細セラミックス粒子を用いる 場合, 攪拌方法の検討が必要である.

プリカーサマトリックスの増粘方法の確立およびプリカー サの気孔率を抑えるといった技術的な課題は残るものの, 鋳 造プリカーサ法を用いて高気孔率のポーラスアルミニウムを 作製可能であることが明らかとなった.

本研究は JSPS 科研費 JP17K14819の助成を受けたものです。

\section{文献}

1) V. Birman and G. A. Kardomateas: Compos. Part B Eng. 142 (2018) 221-240.

2) J. Banhart: Prog. Mater. Sci. 46(2001) 559-632.
3) J. Banhart: Int. J. Vehicle Des. 37(2005) 114-123.

4) J. Banhart: Adv. Eng. Mater. 10(2008) 793-802.

5) K. Kitazono: Mater. Trans. 47(2006) 2223-2228.

6) JIS $7902(2008)$.

7) K. Kitazono, E. Sato and K. Kuribayashi: Scr. Mater. 50(2004) 495-498.

8) K. Kitazono, S. Nishizawa, E. Sato and T. Motegi: Mater. Trans. 45(2004) 2389-2394.

9) Y. Hangai and T. Utsunomiya: Metall. Mater. Trans. A 40 (2009) 275-277.

10) Y. Hangai, T. Utsunomiya and M. Hasegawa: J. Mater. Proc. Technol. 210(2010) 288-292.

11) S. Tsuda, M. Kobashi and N. Kanetake: Mater. Trans. $\mathbf{4 7}$ (2006) 2125-2130.

12) N. Kanetake, M. Kobashi and S. Tsuda: Adv. Eng. Mater. 10 (2008) 840-844.

13) A. E. Simone and L. J. Gibon: Acta Mater. 46(1998) 3109-3123.

14) T. Miyoshi, M. Itoh, S. Akiyama and A. Kitahara: Adv. Eng. Mater. 4(2000) 179-183.

15) A. R. Kennedy: Scr. Mater. 47 (2002) 763-767.

16) B. Matijasevic and J. Banhart: Scr. Mater. 54(2006) 503-508.

17) K. Kadoi, N. Babcsan and H. Nakae: Mater. Trans. 50(2009) 727-733.

18) J. Banhart: Adv. Eng. Mater. 8(2006) 781-794.

19) S. Esmaeelzadeh, A. Simchi and D. Lehmhus: Mater. Sci. Eng. A 424(2006) 290-299.

20) N. Mahmutyazicioglu, O. Albayrak, M. Ipekoglu and S. Altintas: J. Mater. Res. 28(2013) 2509-2519.

21) K. Kadoi and H. Nakae: Mater. Trans. 52(2011) 1912-1919.

22) C. C. Yang, S. Tsao and K. C. Su: J. JFS 67 (1995) 16-19.

23) C. C. Yang and H. Nakae: J. JFS 72 (2000) 593-598.

24) C. C. Yang and H. Nakae: J. Mat. Pro. Tech. 141(2003) 202-206.

25) R. Suzuki, Y. Sakurai and M. Matsubara: J. Japan Inst. Met. Mater. 80(2016) 134-139.

26) D. Yang, J. Chen, H. Wang, J. Jiang, A. Ma and Z. P. Lu: J. Mater. Sci. Technol. 31(2015) 361-368.

27) I. Duarte and J. Banhart: Acta Mater. 48(2000) 2349-2362.

28) S. Asavavisithehai and A. R. Kennedy: Procedia Eng. 32(2012) 714-721.

29) M. Saito, S. Suzuki, P. H. Kamm, F. García-Moreno and J. Banhart: Proc. 9th Int. Conf. on Porous Metals and Metalic Foams, (Barcelona, Spain, 2015) Abstract book, P-107.

30) K. Sekido and K. Kitazono: J. Japan Inst. Met. Mater. 77 (2013) 497-502.

31) A. Shibuya, K. Arihara and Y. Nakamura: Tetsu-to-Hagané 66 (1980) 1550-1556.

32) O. Iwao and Y. Hashizume: J. JILM 32(1982) 622-631.

33) J. Banhart: Adv. Eng. Mater. 8(2006) 781-794.

34) Y. Hangai, Y. Ozeki and T. Utsunomiya: Mater. Trans. 50(2009) 2154-2159.

35) K. Heim, F. G. Moreno and J. Banhart: Scripta Mater. 153(2018) $54-58$.

36) V. Kevorkijan: MJoM 16(2010) 205-219.

37) T. Koizumi, K. Kido, K. Kita, K. Mikado, S. Gnyloskurenko and T. Nakamura: Mater. Trans. 52(2011) 728-733.

38) Y. Hangai, H. Kato, T. Utsunomiya and S. Kitahara: J. Japan Inst. Metals 74 (2010) 697-699.

39) E. Andrews, W. Sanders and L. J. Gibson: Mater. Sci. Eng. A 270(1999) 113-124.

40) Y. Hangai, H. Kato, T. Utsunomiya, S. Kitahara, O. Kuwazuru and N. Yoshikawa: Mater. Trans. 53(2012) 1515-1520. 